\title{
Article \\ Street Sexual Harassment: Experiences and Attitudes among Young Spanish People
}

\author{
Victoria A. Ferrer-Perez ${ }^{1, *} *$, Carmen Delgado-Alvarez ${ }^{2} \oplus$, Andrés Sánchez-Prada ${ }^{2}{ }^{\oplus}$, Esperanza Bosch-Fiol ${ }^{1}$ \\ and Virginia Ferreiro-Basurto ${ }^{1}$ \\ 1 Facultad de Psicología, Universidad de las Islas Baleares, Ctra. Valldemossa, km. 7'5, \\ 07122 Palma de Mallorca, Spain; esperanza.bosch@uib.es (E.B.-F.); virginia.ferreiro@uib.es (V.F.-B.) \\ 2 Facultad de Psicología, Universidad Pontificia de Salamanca, C/Compañía, 1-5, 37002 Salamanca, Spain \\ mcdelgadoal@upsa.es (C.D.-A.); asanchezpr@upsa.es (A.S.-P.) \\ * Correspondence: victoria.ferrer@uib.es
}

\section{check for}

updates

Citation: Ferrer-Perez, V.A.; Delgado-Alvarez, C.; Sánchez-Prada, A.; Bosch-Fiol, E.; Ferreiro-Basurto, V. Street Sexual Harassment: Experiences and Attitudes among Young Spanish People. Int. J. Environ. Res. Public Health 2021, 18, 10375. https:// doi.org/10.3390/ijerph181910375

Academic Editors: Francisca Expósito, Marta Garrido-Macías and Gemma Sáez

Received: 13 September 2021 Accepted: 28 September 2021 Published: 1 October 2021

Publisher's Note: MDPI stays neutra with regard to jurisdictional claims in published maps and institutional affiliations.

Copyright: (c) 2021 by the authors Licensee MDPI, Basel, Switzerland. This article is an open access article distributed under the terms and conditions of the Creative Commons Attribution (CC BY) license (https:// creativecommons.org/licenses/by/ $4.0 /)$.

\begin{abstract}
Violence against women (VAW) is gender-based violence directed at women and girls on account of being female that can take on multiple forms and manifest in different contexts. Among the many possible forms of VAW, this article focuses on "piropos", a type of stranger harassment situation. Specifically, the objectives of this study were two-fold: to analyze the usefulness of a tool to evaluate social attitudes towards this form of VAW and to analyze the influence of sociodemographic variables and prior victimization (whether as a witness or victim) on attitudes towards this type of violence among Spanish youth. An opportunity sample of 538 young Spanish people took part in this study. They filled out a sociodemographic data sheet, a victimization questionnaire designed ad hoc, and a questionnaire on attitudes towards "piropos". The results obtained indicate that the questionnaire was adequate for use as a tool to evaluate social attitudes towards this type of VAW and suggest its applicability for future studies on attitudes towards "piropos" as a type of stranger harassment situation in a Spanish context. Moreover, the results on victimization not only corroborate the magnitude of street sexual harassment in Spain and a direct effect of gender on the perception of the violence experienced, they also reinforce the need to further investigate new aspects. Regarding attitudes towards "piropos", the results obtained indicate that, in general, participants demonstrated negative attitudes or rejection, and these feelings were particularly strong among women.
\end{abstract}

Keywords: street sexual harassment; harassment experiences; "piropos"; attitudes towards harassment

\section{Introduction}

Violence against women (VAW) is a type of gender-based violence directed at women and girls on account of being female that can take on multiple forms and manifest in different contexts [1]. Among the many possible forms of VAW, this study focuses on street sexual harassment (SSH), which constitutes a form of sexual violence [2] and, according to some authors [3-6] may also be referred to as public harassment, sexual harassment in public spaces, or stranger harassment, although others (e.g., [7]) have pointed out the existence of nuances among these different forms of harassment.

Our interest in this type of VAW is rooted in the fact that, while its precise prevalence is difficult to determine, it has been considered "a universaling experience that almost all women share" [8] (p. 534), and can be considered an emerging social problem in our environment given that, although it involves traditionally occurring behaviors, they have only recently been identified as problematic [3,7,9-11]. In fact, although feminist activism during the 1960s and 1970s focused on sexual aggression, intimate partner violence, and later on, sexual harassment (while SSH remained on the sidelines and was considered a lesser problem), this topic has become more relevant, as it forms part of the culture of oppression and continuous sexual and violent predation against women, limiting their 
presence in public spaces, generating fear, and constituting a precursor to physical and sexual victimization, or even femicide [3,10,12-15].

\subsection{Conceptualisation of Street Sexual Harassment (SSH)}

A significant number of studies on this subject have focused on its conceptualization $[2,3,11]$. Thus, in recent decades, numerous definitions have been proposed, with significant variations in the emphasis placed on the different elements that comprise SSH and their specifications [16]. As an example, Bowman [8] defined SSH as "sexual harassment against women in public spaces made by unknown men" (p. 51), and, more recently, SSH has been defined as "unwanted comments, gestures, or actions forced on a stranger in a public space without their consent, directed at them because of their actual or perceived sex, gender, gender expression, or sexual orientation" [17]. In general, all of these definitions include certain common dimensions that allow SSH to be characterized in the following way $[2,3,6,8,10,16,18-21]$ :

(a) Harassment occurs in a public or semi-public space (street, public transport) and is contextualized by a face-to-face interaction between two unknown people, that is, people who share no stable, long-term or safe connection.

(b) Even though stalking, as Lopez [2] points out, is also a type of SSH, this type of violence tends to occur within a brief or even fleeting interaction (which not only constitutes one of its main characteristics, but also differentiates it from other forms of violence, such as sexual harassment in the workplace or academic environment).

(c) The fleeting nature of this behavior and the source of anonymity from which it occurs hinder its evaluation and criminal prosecution [22,23].

(d) The absence of an intimate or other relationship causes the behavior of the harasser to be perceived by the person harassed as an uncomfortable or even threatening transgression of her physical and psychological space.

(e) The behavior is unidirectional (meaning that neither the desires nor situation of the victim are taken into account) with a singular objective (meaning it is not meant to be public nor indiscriminate).

(f) The assault primarily targets women, and the instigators are primarily men (alone or in a group), although SSH may also occur against men, especially those who do not conform to a heteronormative pattern $[11,24]$, or against the non-binary population [25].

(g) Although it may be considered a benign, harmless, or even normalized and socially tolerated act, it is an act of domination that impacts the sexual freedom and right to free movement of women, communicating the message that harassers have the right to occupy public spaces and to control, assault, or injure women. It therefore assumes the imposition of the desires of one (or a few) over another (or others) and has a sexual connotation that is degrading and that objectifies, humiliates, and threatens the woman (or women), provoking in her (them) discomfort or fear.

(h) It may also include visual assault (leering), nonverbal assault (sexual and obscene gestures, sighs, whistles or noises), verbal assault (jeering, sexual comments, whether supposedly positive, offensive or insulting), and/or assault in the sense of physical invasion of privacy (exhibitionism, public masturbation, groping).

\subsection{The Incidence of the Street Sexual Harassment (SSH)}

Another question that has generated considerable interest is the study of the incidence of this type of VAW. Available data corroborate Bowman's assessment [8] of high incidence levels, as previously mentioned. As an example, Table 1 includes some results on this effect in both general terms and specific to the Spanish population, demonstrating that SSH is a serious and far-ranging social problem with a prevalence of women who have experienced it varying between $30 \%$ and $95 \%$, with victims most frequently being younger women. 
Table 1. SSH (street sexual harassment) incidence.

\begin{tabular}{|c|c|c|c|}
\hline Country and Year of the Study & Source & Method & Results \\
\hline Canada, 1993 & MacMillan et al. [26] & General female population survey & More than $80 \%$ of women surveyed had experienced SSH. \\
\hline USA, 2014 & $\begin{array}{l}\text { Kearl [9] } \\
\text { Stop Street Harassment [27] }\end{array}$ & Sociological survey & $\begin{array}{l}\text { SSH is a significant problem in the country. It has been experienced by } \\
65 \% \text { of women, especially in the forms of verbal }(57 \%) \text { and physical } \\
(41 \%) \text { harassment. }\end{array}$ \\
\hline $\begin{array}{l}\text { Foundation Jean Jaurés multi-country } \\
\text { study, 2018-USA }\end{array}$ & Clavaud et al. [28] & $\begin{array}{l}\text { Survey on sexual violence and street } \\
\text { harassment }\end{array}$ & $\begin{array}{l}\text { Fifty-seven percent of women (especially young women) have } \\
\text { experienced at least one SSH situation in their lifetime: } 70 \% \text { whistling; } \\
50 \% \text { sexist comments, teasing or insults; } 46 \% \text { rude gestures with sexual } \\
\text { connotations; } 41 \% \text { touching in a sexual way without their consent. }\end{array}$ \\
\hline Nicaragua, 2014 & Gutierrez \& Lovo [29] & Sociological survey & $\begin{array}{l}\text { More than } 95 \% \text { of women interviewed had experienced at least once } \\
\text { situation of SSH, especially through gestures or verbal language and on } \\
\text { the street, in markets, or on public transport. Nearly } 41 \% \text { had } \\
\text { experienced a strong SSH experience, (experiences that, because of their } \\
\text { severity and context, were remembered as causing more fear, anger, or } \\
\text { frustration, and/or as leading to changes in their routines or behaviors). }\end{array}$ \\
\hline Mexico, Mexico City, 2013 & Campos et al. [30] & Survey & $\begin{array}{l}\text { A total of } 62.8 \% \text { of women who sought services at Mexico City } \\
\text { Government Health Secretariat clinics reported having experienced } \\
\text { some type of SSH in the previous month. }\end{array}$ \\
\hline México, Queretaro, 2014 & Meza \& García [31] & Survey of adolescents aged 13-15 & $\begin{array}{l}\text { Almost half of the adolescents had experienced SSH situations, almost } \\
70 \% \text { of girls had experienced SSH. }\end{array}$ \\
\hline Uruguay, 2013 & UN-Women [32] & Sociological survey about VAW & $\begin{array}{l}\text { More than } 50 \% \text { of women aged } 15-29 \text { had experienced some form of } \\
\text { sexual harassment in public spaces in the previous year. }\end{array}$ \\
\hline Ecuador, Quito, 2012 & UN-Women [32] & Survey on the Quito Safe City Programme & $\begin{array}{l}\text { More than } 65 \% \text { of women had experienced some form of sexual } \\
\text { harassment in the city, often on public transport. }\end{array}$ \\
\hline Chile, 2014 & OCAC [33] & Sociological survey & $\begin{array}{l}\text { A total of } 99.4 \% \text { of women experienced SSH at some point, almost } 40 \% \\
\text { daily, and } 77 \% \text { at least once a week. }\end{array}$ \\
\hline Perú, 2012 & Vallejo \& Rivarola [15] & $\begin{array}{l}\text { National Survey on Family and Gender Roles. } \\
\text { Public Opinion Institute of the PUCP }\end{array}$ & SSH practices mainly affected young women and female students. \\
\hline Perú, Lima, 2016 & Llerena [34] & $\begin{array}{l}\text { Questionnaire administered to female } \\
\text { university students }\end{array}$ & $\begin{array}{l}\text { Ninety-one percent had experienced at least one SSH situation in the } \\
\text { previous year. }\end{array}$ \\
\hline Multi-country study, 2018 & Plan Internacional [17] & $\begin{array}{l}\text { Social survey tool on maps in Madrid, Delhi, } \\
\text { Kampala, Lima, and Sidney }\end{array}$ & $\begin{array}{l}\text { There was a significant volume of SSH complaints perpetrated by } \\
\text { groups on girls and young women in the five cities analyzed, especially } \\
\text { on the street and on public transport. }\end{array}$ \\
\hline
\end{tabular}


Table 1. Cont.

\begin{tabular}{|c|c|c|c|}
\hline Country and Year of the Study & Source & Method & Results \\
\hline $\begin{array}{l}\text { Fondation Jean Jaurés multi-country } \\
\text { study, 2018-Europe }\end{array}$ & Clavaud et al. [28] & $\begin{array}{l}\text { Survey on sexual violence and street } \\
\text { harassment in France, Germany, Spain, Italy, } \\
\text { and United Kingdom }\end{array}$ & $\begin{array}{l}\text { Fifty-six percent of women surveyed (especially young women) had } \\
\text { experienced at least one SSH situation in their lifetime: } 65 \% \text { whistling; } \\
36 \% \text { sexist comments, teasing or insults }\end{array}$ \\
\hline United Kingdom, London, 2012 & UN-Women [35] & No information & $\begin{array}{l}\text { Forty-three percent of young women had experienced SSH in the } \\
\text { previous year. }\end{array}$ \\
\hline France, 2013 & UN-Women [35] & No information & Twenty percent of women had experienced SSH in the previous year. \\
\hline Spain, 2016 & $\begin{array}{l}\text { Rodríguez, et al. [5] } \\
\text { Rodríguez, et al. [36] }\end{array}$ & Analysis of tweets on the topic & $\begin{array}{l}\text { Around } 75 \% \text { of the harassment situations described had occurred in } \\
\text { public places, mainly to young women and in the street. }\end{array}$ \\
\hline Spain, 2016 & $\begin{array}{l}\text { cited in Moya-Garofano } \\
\text { et al. [37] }\end{array}$ & $\begin{array}{l}\text { Questionnaire administered to female } \\
\text { university students }\end{array}$ & $\begin{array}{l}\text { A total of } 25.9 \% \text { of participants had experienced SSH through rude } \\
\text { catcalling } 2-4 \text { times a month, } 17.8 \% \text { at least once a month, and only } 5.5 \% \\
\text { had never experienced catcalling. }\end{array}$ \\
\hline $\begin{array}{l}\text { Fondation Jean Jaurés multi-country } \\
\text { study, 2018-Spain }\end{array}$ & Clavaud et al. [28] & $\begin{array}{l}\text { Survey on sexual violence and } \\
\text { street harassment }\end{array}$ & $\begin{array}{l}\text { Fifty-five percent of women (especially young women) had experienced } \\
\text { at least one SSH situation in their lifetime: } 86 \% \text { whistling; } 76 \% \text { insistent } \\
\text { looks; } 50 \% \text { rude gestures with sexual connotations; } 44 \% \text { insistent } \\
\text { approaches without consent, and } 40 \% \text { following, or sexist comments, } \\
\text { teasing or insults. }\end{array}$ \\
\hline
\end{tabular}

VAW: Violence Against Women; PUCP: Pontificia Universidad Católica de Perú. 
It is worth noting that incidence studies use different types of tools, with a predominance of sociological-based surveys, (i.e., $[28,33,38]$ ), although some questionnaires have been developed for this purpose (i.e., $[18,34,39,40])$.

\subsection{The Types of Street Sexual Harassment (SSH)}

Another aspect worth highlighting is that among the different types of SSH already mentioned, with the so-called "piropos" being among the most common $[4,17,30,33,37,41]$. These involve, as noted by Vallejo and Rivarola [15], and Farmer and Smock [7] or Ledezma [42], among others, verbal and nonverbal signals (including whistling, leering, comments about the person's physical appearance, looking for attention, etc.) focused on physical aspects of the objectified women and is habitually are socially normalized and even romanticized, which could lead such behaviors to be deemed positive by society and/or by the recipient $[37,41]$. In general, these behaviors have no legal consequences for those who instigate them (for an analysis of this situation in Spain, see, for example, Brox [22], or Rodemann [23]), but may have behavioral or psychological effects for the recipient, including the avoidance of certain spaces or places, modifying the way they dress or their posture, or provoking negative emotions $[2,4,15,20,43]$. It is also worth noting that "piropos" may vary according to their intention and valence, so some behaviors may be specifically rude, vulgar, lewd, and lascivious with sexual undertones and a negative sense (more in line with the idea of catcalls), while others may have a pleasant or flattering connotation in a positive sense (more in line with the idea of flattering remarks) [37,41], and due to this distinction, a controversy arises as to whether all "piropos" are rejectable. One possible response has emerged from several studies (i.e., [37,41]), bringing to light the idea that "piropos" made by strangers generate negative effects (different, but negative in any case), regardless of whether the recipient deems them to be positive or negative. Another option could be to distinguish a "piropo" from a flattering remark with the understanding that the latter (as opposed to the former) occurs in the context of a previous interaction or relationship, is relative to a particular characteristic or quality that the recipient possesses, and is deemed to be positive by both the speaker and the listener (if the "piropo" comes from a stranger, it is intrusive and constitutes an objectification and a form of control) $[2,3]$.

\subsection{The Perception of Street Sexual Harassment (SSH)}

In addition to analyze the incidence and most frequent typologies of SSH, other studies focused on learning how to live through an SSH experience and the psychological trauma it might produce (discomfort, fear, threat; i.e., $[13,33,44]$ ); understanding the answers and strategies that can be used to deal with these incidents (i.e., $[7,15])$; investigating how victims react when facing specific SSH behaviors, such as "piropo" (i.e., [37,41]); analyzing the consequences of SSH on the victim's health (i.e., $[45,46])$ ); or determining the role of, and interventions by, witnesses to cases of VAW (i.e., [47]).

As noted by Logan [10], the majority of studies on SSH have focused on the individual level, and very few have looked at the social dimension when, in fact, this form of VAW is a social problem with social consequences that reproduce and reinforce inequalities. In this regard, it is worth recalling the fact that the use of VAW as a means to control women and limit their independence and presence in public spaces is not in the least bit new (i.e., Browmiller [48]). Indeed, SSH sends messages to the victims as well as the aggressor, and even to the witnesses "about the power, the violence, the equality, the civic responsibility, the public space, and the freedom" [10] (p. 206). This suggests that SSH is not only a form of VAW and sexual violence but also a symbolic violence in that it brings to light the limitations that a patriarchal society imposes on the freedom and mobility of women and restricts their use of public spaces at certain times and places [2-4,19,43].

\subsection{The Beliefs and Attitudes towards Street Sexual Harassment (SSH)}

To this end, it is important to remember that the beliefs and attitudes towards VAW (in general and in its different manifestations) play an important role in the perpetration of 
these types of violence and in the response of the women who suffer from these experiences as well as the communities in which they occur $[49,50]$. According to a previously described proposition by Logan [10], the study of social attitudes towards SSH is particularly relevant, because it determines the social norms towards this type of violence and the formal and informal responses it evokes, such that a climate of acceptance and favorable and/or tolerant beliefs and attitudes becomes a risk factor for the proliferation of SSH.

These attitudes may be influenced by different factors, including the victim's, or even the harasser's, sociodemographic characteristics or the effects of the context or of sexism $[18,38,51,52]$. This is why, for example, the fact that SSH is primarily endured by women could have a direct (greater perception of this violence by women) (i.e., [53]) or indirect (mediated by the gender role and/or sexism) (i.e., [18,54] effect on the perception of the violence endured by the victim.

\subsection{Study Objectives}

Given the relevance of SSH and "piropos" in general, and particularly in the Spanish context [41], and given the still-limited volume of empirical studies on the matter in Spain (see Table 1), this study focused on "piropos" as a type of stranger harassment situation. Its objectives were two-fold: to analyze the usefulness of a tool to evaluate social attitudes towards this form of VAW and to analyze the influences of sociodemographic variables and prior victimization (whether as a witness or victim) on attitudes towards this type of violence among Spanish youth.

\section{Materials and Methods}

\subsection{Participants}

An opportunity sample of 538 Spanish young people aged between 18 and 30 years $(\mathrm{M}=21.51$, D.T. $=2.70)$ took part in this study. Regarding gender, all participants in the study sample categorized themselves as either female or male, of which $397(73.8 \%)$ were female and $141(26.2 \%)$ were male. Their characteristics are presented in Table 2.

Table 2. Sample description.

\begin{tabular}{|c|c|c|}
\hline Variable & Classification & $n(\%)$ \\
\hline \multirow{4}{*}{ Educational level } & Primary & $3(0.6 \%)$ \\
\hline & Secondary & $310(57.6 \%)$ \\
\hline & Professional training & $64(11.9 \%)$ \\
\hline & University & $161(29.9 \%)$ \\
\hline \multirow{4}{*}{ Labor situation } & Unemployed & $38(16.5 \%)$ \\
\hline & Employed & $139(25.8 \%)$ \\
\hline & Students & $360(66.9 \%)$ \\
\hline & No reply & $1(0.2 \%)$ \\
\hline \multirow{5}{*}{ Economical level } & Low & $89(16.5 \%)$ \\
\hline & Medium-low & $155(28.8 \%)$ \\
\hline & Medium-medium & $242(45.0 \%)$ \\
\hline & Medium-high & $50(9.3 \%)$ \\
\hline & High & $2(0.4 \%)$ \\
\hline \multirow{5}{*}{ Political opinion } & Left & $371(69.0 \%)$ \\
\hline & Centre & $106(19.7 \%)$ \\
\hline & Right & $35(6.5 \%)$ \\
\hline & Others & $1(0.2 \%)$ \\
\hline & No reply & $23(4.3 \%)$ \\
\hline \multirow{3}{*}{ Current partner } & Yes & $79(14.7 \%)$ \\
\hline & No & $452(84.0 \%)$ \\
\hline & No reply & $7(1.3 \%)$ \\
\hline
\end{tabular}


Based on the age variable, two groups were created: individuals aged 18 to 21 years (late adolescents or youths; $n=307 ; 57.1 \%$ ) and those aged 22 to 30 years (young adults; $n=231 ; 42.9 \%$ ). This division took into account life expectancy and the age range of the participants and essentially corresponds to the difference between Generation $\mathrm{Z}$ or Centennials (born between 1995 and 2009) [55] and Generation Y or Millennials (born between 1981 and 1994) [56]. The distribution between males and females in these groups was homogeneous: $75.6 \%$ of girls in the $18-21$ age group and $71.4 \%$ in the $22-30$ age group $\left(\chi^{2}(1, n=538)=0.322, p=0.163\right)$.

\subsection{Instruments}

Data collection was accomplished via a questionnaire that included the following:

- A sociodemographic data sheet with information related to gender (self-categorized by participants), age, economic level, current work status, and political opinion.

- A victimization questionnaire designed ad hoc, including eight questions with a 4-point scale answer relative to the frequency (1: No, never; 2: Yes, on one occasion; 3 : Yes, on more than one occasion; and 4: Yes, regularly) with which the participants had been victims of (4 questions) or witness to (4 questions) 4 types of violence: robbery, $\mathrm{SSH}$, sexual harassment, and intimate partner violence.

- A questionnaire on attitudes towards "piropos" [40] to measure attitudes towards a SSH situation: "piropos". The following situation was presented: a young girl is walking alone down a street and receives the sexual attention of a group of young males, specifically a comment from one of them about 'how hot she is'. The participants were asked to evaluate their perception of this situation, indicating their level of agreement according to a Likert scale (where 1 means 'Not at all' and 7 means 'A lot') regarding 7 items characterizing the situation (as fun, pleasant, flattering, male chauvinist, offensive, unpleasant, vulgar). For items 1,2, and 3, the order of the scoring scale was inverted prior to the analysis so that higher scores reflected a negative attitude or rejection of the remark. According to the author, the scale offers good internal consistency $(\alpha=0.91)$.

\subsection{Procedure}

A non-probability convenience sample was used. The questionnaire used to gather information was prepared on the Lime Survey platform and disseminated through social network sites used by the researchers and their collaborators. An introductory text about the objectives and conditions of the study was included, and access to the answer sheet implied prior agreement of the participants to take part in the study.

\subsection{Data Analysis}

The psychometric adjustment of the Questionnaire on Attitudes towards "piropos" in this sample was verified with a reliability analysis using Cronbach's alpha and an Exploratory Factor Analysis based on the principal axis factoring method to test its unidimensionality, as proposed in Moya-Garofano's original version [40]. This was followed by a descriptive analysis of the frequency with which the types of victimization under study appeared, and a chi-squared test was applied to explore the relationship with gender. ALSCAL (Alternating Least Square Analysis) Multidimesional Scaling was applied to explore the relationships among the different types of victimization and to identify a possible underlying substructure. In order to study differences regarding the frequency of the different types of victimization studied and the attitudes towards stranger harassment according to gender and age, the Student's $t$-test for independent samples was used, after previously confirming the homoscedasticity of each variable with the Levene test for homogeneity of variance. If the measure of homoscedasticity $(p>0.05)$ was met, the $t$-value for the homogeneity of variance was used, and when it was not met, the value of $t$ was taken with non-homogenous variance once the degrees of freedom had been corrected. In order to identify which variables of victimization (as a witness or victim) were predictive 
of attitudes towards stranger harassment among men and women according to age, a stepwise multiple regression analysis was performed. Finally, the differences in attitudes towards stranger harassment based on the other sociodemographic variables under study were analyzed using ANOVA. If the measure of homoscedasticity $(p>0.05)$ (determined via the Levene test) was not met, a contrast post-hoc test was applied to the different groups using the Games-Howel test for non-homogeneous groups. It should be noted that, due to the small size of some subsamples, some variables were recoded. Socioeconomic status was recoded into three categories (low and lower middle, middle-middle, and upper middle and upper). Regarding political ideology, only three categories were compared: left, right, and center. Regarding level of education, participants with primary level education were not taken into account.

\section{Results}

\subsection{Psychometric Properties of the Questionnaire on Attitudes towards "Piropos"}

The internal consistency of the scale as a whole was satisfactory with a Cronbach's alpha value of 0.884 . The Exploratory Factor Analysis based on the principal axis factoring method (after inverting the scores for items 1 to 3 ) yielded a solution with a non-rotation matrix, accounting for $69.48 \%$ of variance and a general factor (Factor 1) accounting for $56.43 \%$ of variance. The factorial load is presented in Table 3. This result confirms the unidimensionality of the scale, which was deemed to be adequate to obtain a general score from the sum of the items (inverting the scores for items 1 to 3 ), as formulated in the original version. Using this scale, the total possible score of attitudes towards "piropos" varied between 7 and 49 , with higher scores reflecting more negative attitudes or rejection of this type of stranger harassment situation.

Table 3. Factor loadings of the Questionnaire on Attitudes towards "Piropos".

\begin{tabular}{ccc}
\hline \multirow{2}{*}{ Items } & \multicolumn{2}{c}{ Unrotated Matrix } \\
\cline { 2 - 3 } & Factor 1 & Factor 2 \\
\hline 1. It is fun * & 0.696 & 0.499 \\
\hline 2. It is nice * & 0.599 & 0.515 \\
\hline 3. It is flattering * & 0.699 & 0.318 \\
\hline 4. It is sexist (macho) & 0.738 & -0.211 \\
\hline 5. It is offensive & 0.800 & -0.298 \\
\hline 6. It is unpleasant & 0.846 & -0.313 \\
\hline 7. It is disgusting & 0.848 & -0.259 \\
\hline
\end{tabular}

* Recoded scores.

\subsection{Frequencies of the Different Types of Victimization and Relationship with Gender}

The frequency distribution, as shown in Table 4, indicated a clear pattern based on gender. An analysis of the relationship between type of victimization and gender (based on a chi-squared test) showed that, while the frequency with which the participants were witnesses and/or victims of theft was independent of their gender, there was a statistical relationship between these two variables for the other forms of victimization analyzed, indicating that, in all cases, women had more frequently experienced being a witness or victim. 
Table 4. Frequency of victimization by gender.

\begin{tabular}{|c|c|c|c|c|c|}
\hline Type & Frequency & Gender & Witness & Victim & $\chi^{2}(3 \mathrm{df})$ \\
\hline \multirow{7}{*}{$\begin{array}{c}\text { Robbery } \\
n=453\end{array}$} & Never & Men & $50(41.7 \%)$ & $75(62.5 \%)$ & \multirow{7}{*}{$\begin{array}{c}\text { Witness } \\
\chi^{2}=7.37 \\
p=0.061 \\
\text { Victim } \\
\chi^{2}=1.56 \\
p=0.459\end{array}$} \\
\hline & \multirow{2}{*}{ Once } & Men & $35(29.2 \%)$ & $36(30.0 \%)$ & \\
\hline & & Women & $96(28.8 \%)$ & $82(24.6 \%)$ & \\
\hline & \multirow{2}{*}{ More than once } & Men & $34(28.3 \%)$ & $9(7.5 \%)$ & \\
\hline & & Women & $66(19.8 \%)$ & $32(9.6 \%)$ & \\
\hline & \multirow{2}{*}{ Usually } & Men & $1(0.8 \%)$ & - & \\
\hline & & Women & - & - & \\
\hline \multirow{8}{*}{$\begin{array}{c}\text { Intimate } \\
\text { Partner } \\
\text { Violence } \\
n=537\end{array}$} & \multirow{2}{*}{ Never } & Men & $83(58.9 \%)$ & $124(87.9 \%)$ & \multirow{8}{*}{$\begin{array}{c}\text { Witness } \\
\chi^{2}=38.75 \\
p<0.001 \\
\text { Victim } \\
\chi^{2}=17.30 \\
p=0.001\end{array}$} \\
\hline & & Women & $122(30.8 \%)$ & $279(70.3 \%)$ & \\
\hline & & Men & $20(14.2 \%)$ & $11(7.8 \%)$ & \\
\hline & Once & Women & $112(28.2 \%)$ & $67(16.9 \%)$ & \\
\hline & & Men & $30(27.0 \%)$ & $6(4.3 \%)$ & \\
\hline & More than once & Women & $145(36.6 \%)$ & $48(12.1 \%)$ & \\
\hline & \multirow{2}{*}{ Usually } & Men & - & - & \\
\hline & & Women & $17(4.3 \%)$ & $2(0.5 \%)$ & \\
\hline \multirow{8}{*}{$\begin{array}{l}\text { Sexual Harassment } \\
\qquad n=537\end{array}$} & \multirow{2}{*}{ Never } & Men & $64(45.4 \%)$ & $110(78.0 \%)$ & \multirow{8}{*}{$\begin{array}{c}\text { Witness } \\
\chi^{2}=22.62 \\
p<0.001 \\
\text { Victim } \\
\chi^{2}=38.10 \\
p<0.001\end{array}$} \\
\hline & & Women & $124(31.2 \%)$ & $191(48.2 \%)$ & \\
\hline & Onso & Men & $24(17.0 \%)$ & $15(10.6 \%)$ & \\
\hline & Unce & Women & $37(9.3 \%)$ & $92(23.2 \%)$ & \\
\hline & & Men & $49(34.8 \%)$ & $16(11.3 \%)$ & \\
\hline & More than once & Women & $196(49.5 \%)$ & $106(26.8 \%)$ & \\
\hline & \multirow{2}{*}{ Usually } & Men & $4(2.8 \%)$ & - & \\
\hline & & Women & $39(9.8 \%)$ & $7(1.8 \%)$ & \\
\hline \multirow{8}{*}{$\begin{array}{c}\text { Street } \\
\text { Sexual } \\
\text { Harassment } \\
n=537\end{array}$} & \multirow{2}{*}{ Never } & Men & $42(29.8 \%)$ & $81(57.4 \%)$ & \multirow{8}{*}{$\begin{array}{c}\text { Witness } \\
\chi^{2}=57.39 \\
p<0.001 \\
\text { Victim } \\
\chi^{2}=230.5 \\
p<0.001\end{array}$} \\
\hline & & Women & $40(10.1 \%)$ & $21(5.3 \%)$ & \\
\hline & \multirow{2}{*}{ Once } & Men & $18(12.8 \%)$ & $25(17.7 \%)$ & \\
\hline & & Women & $30(7.6 \%)$ & $23(5.8 \%)$ & \\
\hline & \multirow{2}{*}{ More than once } & Men & $70(49.6 \%)$ & $34(24.1 \%)$ & \\
\hline & & Women & $187(47.1 \%)$ & $235(59.3 \%)$ & \\
\hline & \multirow{2}{*}{ Usually } & Men & $11(7.8 \%)$ & $1(0.7 \%)$ & \\
\hline & & Women & $139(35.0 \%)$ & $117(29.5 \%)$ & \\
\hline
\end{tabular}

\subsection{Relationships among Different Types of Victimization}

Given the previously described results and the unequal sizes of the subsamples of women and men, ALSCAL Multidimensional Scaling was applied to each subsample separately to explore the relationships between the frequencies of different types of victimization, with witnesses or victims assessed separately in both subsamples. The results obtained indicate a clear underlying substructure among the women but not among the men.

Specifically, a bidimensional structure with excellent fit values was obtained from the sample of females (S-stress $=0.026, \mathrm{RSQ}=0.997$ ). Figure 1 shows that theft (as either victim or witness) constitutes an obviously different form of victimization, while the grouping of intimate partner violence and sexual harassment emerged from direct experiences as a victim. SSH (whether as witness or victim) constitutes a different grouping from other types of victimization. 


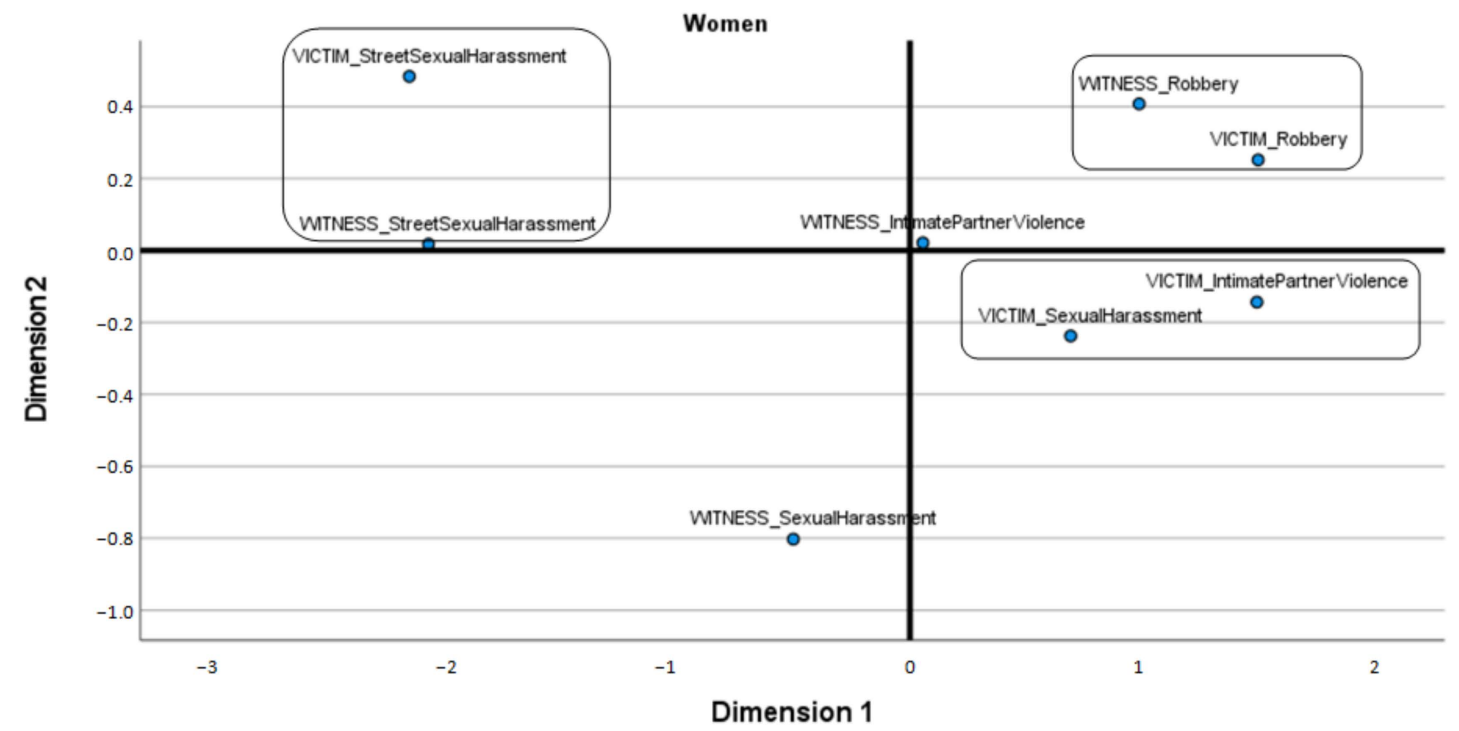

Figure 1. Multidimensional scaling of victimization types in women.

On the other hand, a different structure with poor fit values was obtained from the sample of males (Figure 2) (S-stress $=0.085, \mathrm{RSQ}=0.970$ ), which does not allow for clear interpretation of the configuration.

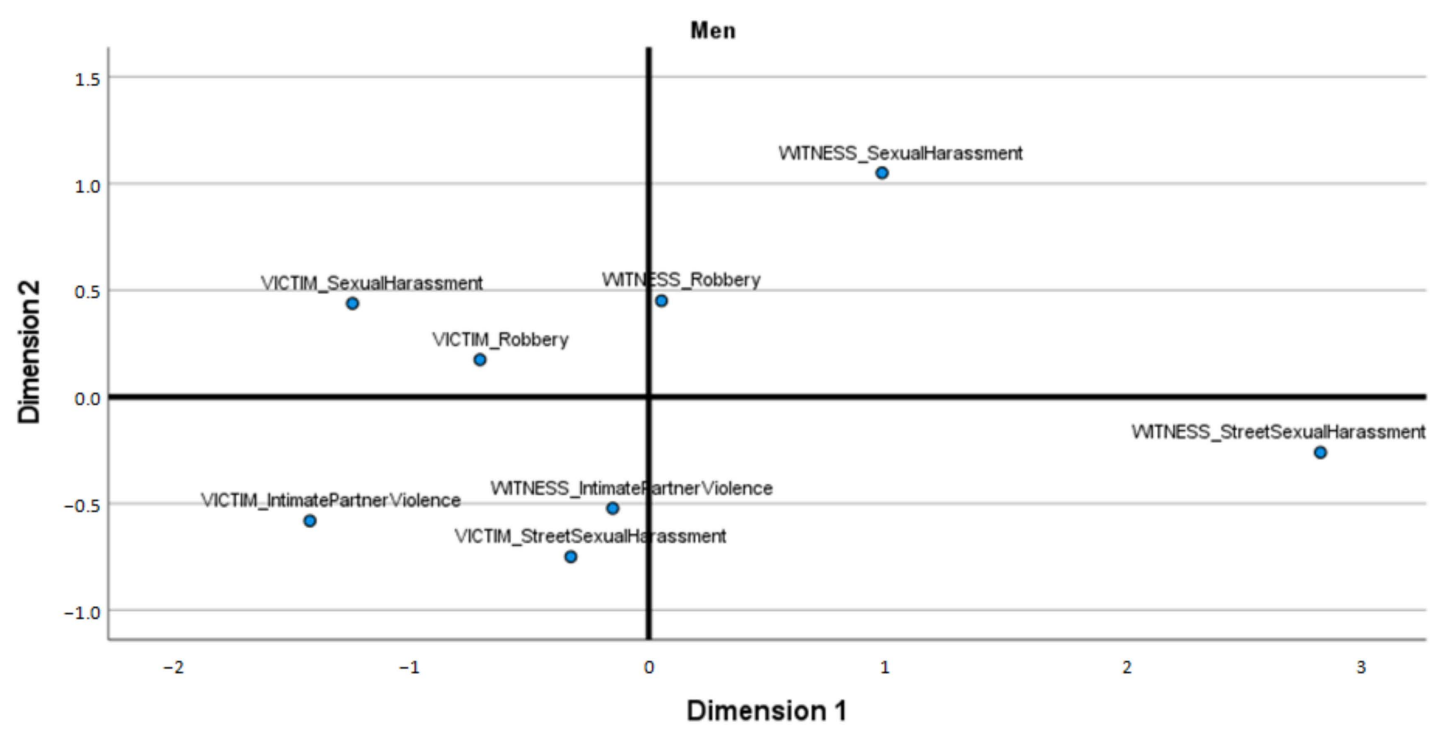

Figure 2. Multidimensional scaling of victimization types in men.

\subsection{Victimization and Attitudes towards "Piropos" by Gender}

An analysis of the differences in victimization by gender (Table 5, Figure 3) showed that there were no statistically significant differences between men and women with regard to being a victim of theft; men were witnesses of theft with a higher statistically significant frequency than women, and for the three forms of VAW studied (intimate partner violence, sexual harassment and SSH), women had been a witness or victim with a significantly higher frequency than men. Regarding attitudes towards "piropos", both men and women presented higher than average scores (greater than 42.70 points from a maximum of 49 points), which implies negative attitudes towards, or rejection of, such actions, although women showed significantly greater rejection of this type of SSH situation than men (Table 5). 
Table 5. Victimization and attitudes toward "piropos" by gender.

\begin{tabular}{|c|c|c|c|c|c|c|c|}
\hline Variable & Lévène $(p)$ & Gender & $n$ & Mean $(S D)$ & $d f$ & $t$ Student & $p$ \\
\hline $\begin{array}{l}\text { Witness to } \\
\text { Robbery }\end{array}$ & 0.399 & $\begin{array}{c}\text { Men } \\
\text { Women }\end{array}$ & $\begin{array}{l}120 \\
333\end{array}$ & $\begin{array}{l}1.88(0.852) \\
1.68(0.784)\end{array}$ & 471 & 2.326 & 0.020 \\
\hline $\begin{array}{l}\text { Witness to Intimate } \\
\text { Partner Violence }\end{array}$ & 0.716 & $\begin{array}{c}\text { Men } \\
\text { Women }\end{array}$ & $\begin{array}{l}141 \\
396\end{array}$ & $\begin{array}{l}1.68(0.873) \\
2.14(0.910)\end{array}$ & 535 & -5.246 & $<0.001$ \\
\hline $\begin{array}{c}\text { Witness to } \\
\text { Sexual Harassment }\end{array}$ & 0.088 & $\begin{array}{c}\text { Men } \\
\text { Women }\end{array}$ & $\begin{array}{l}141 \\
396\end{array}$ & $\begin{array}{l}1.95(0.959) \\
2.38(1.030)\end{array}$ & 535 & -4.316 & $<0.001$ \\
\hline $\begin{array}{l}\text { Witness to Street } \\
\text { Sexual Harassment }\end{array}$ & 0.000 & $\begin{array}{c}\text { Men } \\
\text { Women }\end{array}$ & $\begin{array}{l}141 \\
396\end{array}$ & $\begin{array}{l}2.35(0.994) \\
3.07(0.910)\end{array}$ & 228.779 & -7.536 & $<0.001$ \\
\hline $\begin{array}{l}\text { Victim of } \\
\text { Robbery }\end{array}$ & 0.673 & $\begin{array}{c}\text { Men } \\
\text { Women }\end{array}$ & $\begin{array}{l}120 \\
333\end{array}$ & $\begin{array}{l}1.45(0.633) \\
1.44(0.663)\end{array}$ & 451 & 0.169 & 0.868 \\
\hline $\begin{array}{l}\text { Victim of Intimate } \\
\text { Partner Violence }\end{array}$ & 0.000 & $\begin{array}{c}\text { Men } \\
\text { Women }\end{array}$ & $\begin{array}{l}141 \\
396\end{array}$ & $\begin{array}{l}1.16(0.472) \\
1.43(0.720)\end{array}$ & 376.230 & -4.902 & $<0.001$ \\
\hline $\begin{array}{c}\text { Victim of } \\
\text { Sexual Harassment }\end{array}$ & 0.000 & $\begin{array}{c}\text { Men } \\
\text { Women }\end{array}$ & $\begin{array}{l}141 \\
396 \\
\end{array}$ & $\begin{array}{l}1.33(0.673) \\
1.82(0.889)\end{array}$ & 323.972 & -6.756 & $<0.001$ \\
\hline $\begin{array}{l}\text { Victim of Street } \\
\text { Sexual Harassment }\end{array}$ & 0.000 & $\begin{array}{c}\text { Men } \\
\text { Women }\end{array}$ & $\begin{array}{l}141 \\
396\end{array}$ & $\begin{array}{l}1.68(0.865) \\
3.13(0.741)\end{array}$ & 217.650 & -17.734 & $<0.001$ \\
\hline $\begin{array}{l}\text { Attitudes toward } \\
\text { "piropos" }\end{array}$ & 0.000 & $\begin{array}{c}\text { Men } \\
\text { Women }\end{array}$ & $\begin{array}{l}139 \\
396\end{array}$ & $\begin{array}{l}42.72(7.73) \\
45.82(6.73)\end{array}$ & 207.499 & -4.243 & $<0.001$ \\
\hline
\end{tabular}

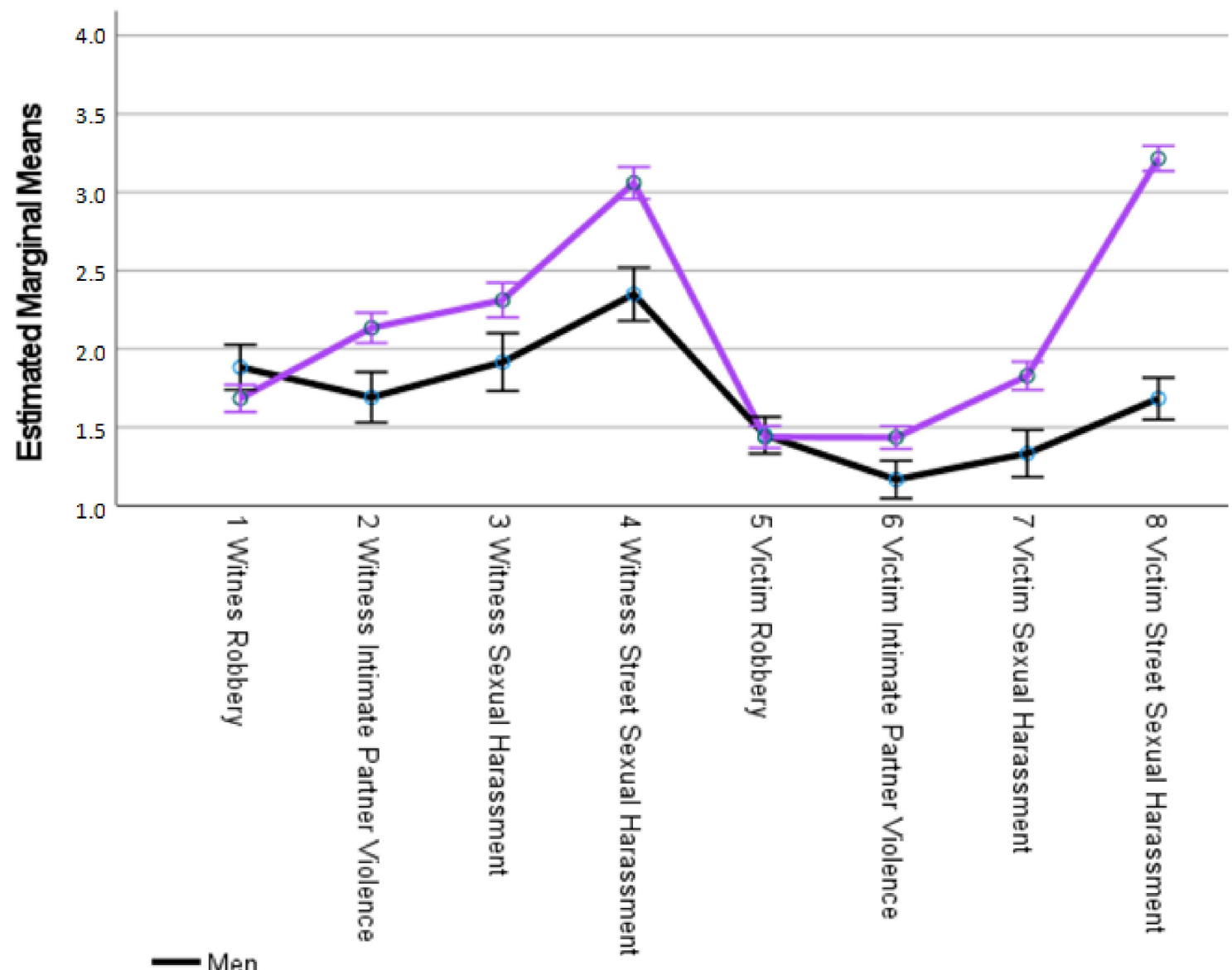

Figure 3. Differences in victimization types by gender. 


\subsection{Victimization and Attitudes towards "Piropos" by Age}

An analysis of the differences in victimization by age (see Table 6, Figure 4) showed that the only statistically significant differences were related to victimization by theft, as either a witness or victim, with both occurrences significantly more frequently among participants aged 22 to 30 than among those aged 18 to 21 .

Table 6. Victimization and attitudes toward "piropos" by age.

\begin{tabular}{|c|c|c|c|c|c|c|c|}
\hline Variable & Lévène $(p)$ & Age & $n$ & Mean $(S D)$ & $d f$ & $t$ Student & $p$ \\
\hline Witness to & \multirow{2}{*}{0.581} & $18-21$ & 229 & $1.65(0.785)$ & \multirow{2}{*}{451} & \multirow{2}{*}{-2.443} & \multirow{2}{*}{0.015} \\
\hline Robbery & & $22-30$ & 224 & $1.83(0.819)$ & & & \\
\hline Witness to Intimate & \multirow{2}{*}{0.478} & $18-21$ & 306 & $2.00(0.934)$ & \multirow{2}{*}{535} & \multirow{2}{*}{-0.646} & \multirow{2}{*}{0.519} \\
\hline Partner Violence & & $22-30$ & 231 & $2.05(0.907)$ & & & \\
\hline Witness to & \multirow{2}{*}{0.874} & $18-21$ & 306 & $2.25(1.031)$ & \multirow{2}{*}{535} & \multirow{2}{*}{-0.295} & \multirow{2}{*}{0.768} \\
\hline Sexual Harassment & & $22-30$ & 231 & $2.28(0.1027)$ & & & \\
\hline Witness to Street & \multirow{2}{*}{0.355} & $18-21$ & 306 & $2.95(0.976)$ & \multirow{2}{*}{535} & \multirow{2}{*}{1.805} & \multirow{2}{*}{0.072} \\
\hline Sexual Harassment & & $22-30$ & 231 & $2.80(0.990)$ & & & \\
\hline Victim of & \multirow{2}{*}{0.000} & $18-21$ & 229 & $1.34(0.590)$ & \multirow{2}{*}{434.971} & \multirow{2}{*}{-3.348} & \multirow{2}{*}{0.001} \\
\hline Robbery & & $22-30$ & 224 & $1.54(0.701)$ & & & \\
\hline Victim of Intimate & \multirow{2}{*}{0.682} & $18-21$ & 306 & $1.35(0.677)$ & \multirow{2}{*}{535} & \multirow{2}{*}{-0.311} & \multirow{2}{*}{0.756} \\
\hline Partner Violence & & $22-30$ & 231 & $1.37(0.672)$ & & & \\
\hline Victim of & \multirow{2}{*}{0.693} & $18-21$ & 306 & $1.71(0.860)$ & \multirow{2}{*}{535} & \multirow{2}{*}{0.405} & \multirow{2}{*}{0.685} \\
\hline Sexual Harassment & & $22-30$ & 231 & $1.68(0.871)$ & & & \\
\hline Victim of Street & \multirow{2}{*}{0.008} & $18-21$ & 306 & $2.77(1.063)$ & \multirow{2}{*}{524.602} & \multirow{2}{*}{0.465} & \multirow{2}{*}{0.636} \\
\hline Sexual Harassment & & $22-30$ & 231 & $2.73(0.923)$ & & & \\
\hline Attitudes toward & \multirow[b]{2}{*}{0.163} & $18-21$ & 305 & $45.35(6.149)$ & \multirow{2}{*}{533} & \multirow{2}{*}{1.329} & \multirow{2}{*}{0.185} \\
\hline "piropos" & & $22-30$ & 230 & $44.56(7.730)$ & & & \\
\hline
\end{tabular}

Regarding attitudes towards "piropos", both age groups presented higher than average scores (greater than 44.50 points from a maximum of 49 points), implying negative attitudes or rejection of this type of SSH situation with no observable statistically significant differences between both groups (Table 6).

3.6. Relationship between Victimization and Attitude towards "Piropos" as a Function of Gender and Age

According to the analyses performed by gender, among men, no variables of victimization entered the regression equation, which led us to conclude that none of the victimization variables under study were statistically significantly predictive of their attitudes towards "piropos". Among the women, the act of witnessing SSH was the only variable of victimization that was shown to serve as a statistically significant predictor of attitudes towards "piropos" with a direct relationship (change in $\mathrm{R}^{2}=0.025 ; p=0.004$; $\beta=0.158$ ); in other words, having been witness to SSH predicted greater rejection of a SSH situation, such as "piropos".

By age, the victimization variables that were found to be statistically significant predictors of attitudes towards "piropos" among the younger participants (aged 18 to 21) were witnessing SSH (change in $\mathrm{R}^{2}=0.036 ; p=0.004 ; \beta=0.142$ ), theft (change in $\mathrm{R}^{2}=0.031$; $p=0.007 ; \beta=-0.227$ ), or intimate partner violence (change in $\mathrm{R}^{2}=0.031 ; p=0.006$; $\beta=0.195)$. In other words, witnessing SSH or intimate partner violence is predictive of greater rejection of "piropos" (direct relation), while witnessing theft is predictive of lesser rejection of "piropos" (inverse relation). Among participants aged 22 to 30, the only predictive victimization variable of attitudes towards "piropos" was having been a victim of SSH (change in $\mathrm{R}^{2}=0.022 ; p=0.025 ; \beta=0.150$ ); that is, having experienced SSH is predictive of greater rejection of this type of SSH situation. 


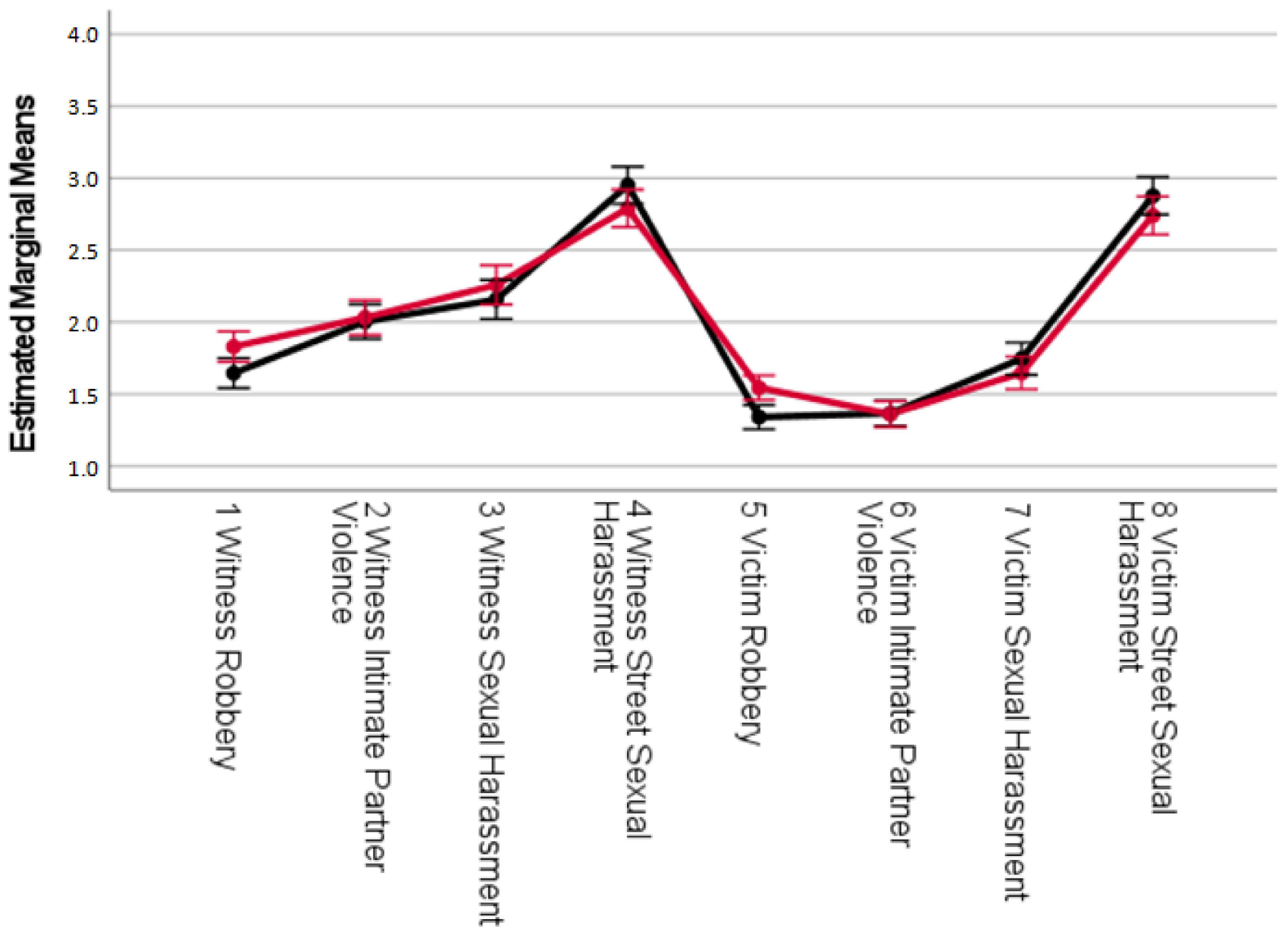

Figure 4. Differences in victimization types by age.

\subsection{Attitudes towards "Piropos" and Other Sociodemographic Variables}

In general terms, all subgroups analyzed as functions of the different categories under study had above average point scores (greater than 40.50 points of a maximum 49 points) on the scale of attitudes towards "piropos", which suggested the presence of negative attitudes or rejection (Table 7). Regarding observable differences, although the F contrast statistic was significant for the work status and socioeconomic status, there were no significant differences in any of the respective groups for each variable when comparing them and correcting for the effect of homogeneity of variance. The only variable that was suggested to have significant effects on the groups was political ideology. Specifically, those who claimed a more 'left-leaning' affiliation scored more negatively or had a greater rejection of "piropos" than those who claimed a more 'center' or 'right-leaning' affiliation. 
Table 7. Attitudes toward "piropos" and other socio-demographic variables.

\begin{tabular}{|c|c|c|c|c|c|c|c|}
\hline Variable & Classification & $n$ & Mean & $S D$ & $F$ & $p$ & G.-H* \\
\hline \multirow{3}{*}{ Educational level } & Secondary & 307 & 45.03 & 6.97 & \multirow{3}{*}{$\mathrm{F}(2.529)=0.850$} & \multirow{3}{*}{0.428} & \multirow{3}{*}{---} \\
\hline & Professional training & 64 & 44.08 & 8.01 & & & \\
\hline & University & 161 & 45.40 & 6.20 & & & \\
\hline \multirow{3}{*}{ Labor situation } & Unemployed & 38 & 42.47 & 9.88 & \multirow{3}{*}{$\mathrm{F}(2.529)=4.325$} & \multirow{3}{*}{0.014} & \multirow{3}{*}{ N.S. ** } \\
\hline & Employed & 138 & 44.33 & 7.73 & & & \\
\hline & Students & 358 & 45.53 & 6.04 & & & \\
\hline \multirow{3}{*}{ Economical level } & Low/Medium-low & 243 & 44.94 & 7.20 & \multirow{3}{*}{$\mathrm{F}(2.532)=3.402$} & \multirow{3}{*}{0.034} & \multirow{3}{*}{ N.S. ${ }^{* *}$} \\
\hline & Medium-medium & 241 & 45.55 & 5.84 & & & \\
\hline & Medium-high/High & 51 & 42.80 & 9.20 & & & \\
\hline \multirow{3}{*}{ Political opinion } & Left & 369 & 46.49 & 5.48 & \multirow{3}{*}{$F(2.506)=24.774$} & \multirow{3}{*}{$<0.001$} & \multirow{3}{*}{$\begin{array}{l}\text { Left-Centre } \\
\text { Left-Right }\end{array}$} \\
\hline & Centre & 105 & 42.82 & 8.19 & & & \\
\hline & Right & 35 & 40.54 & 7.69 & & & \\
\hline \multirow{2}{*}{ Current partner } & Yes & 79 & 45.44 & 5.701 & \multirow{2}{*}{$\mathrm{F}(1.529)=0.346$} & \multirow{2}{*}{0.557} & \\
\hline & No & 452 & 44.95 & 7.076 & & & \\
\hline
\end{tabular}

${ }^{*} p$ - significance of Games-Howel post-hoc test for non-homogeneous groups. ${ }^{* *}$ N.S.: non-significant difference between a pair of groups. $* * *$ Significant differences between Left-Centre $(p<0.001)$ and Left-Right $(p<0.001)$. No differences between Centre-Right opinion $(p=0.302)$.

\section{Discussion}

The results obtained indicate the adequacy of the Questionnaire of Attitudes towards "piropos" [40] as a tool to specifically evaluate social attitudes towards this type of VAW in the study sample within a Spanish context, suggesting their adequate reliability and supporting the author's use of a unidimensional point scale. It should be noted that an important type of tool available for analyzing SSH is sociological-based surveys [28,33,38]; therefore, the availability of a questionnaire suitable for this purpose could be very useful for research on the topic. Moreover, although some related studies $[18,34,39]$ report evaluate attitudes and beliefs regarding SSH using questionnaires, a review of their content and contributions showed different objectives (such as to determine which components of SSH are perceived by women who have experienced them, or to estimate the frequency of SSH), and demonstrated they were developed in different cultural contexts outside of Spain (such as Venezuela, Paraguay or Peru). In this sense, the results regarding the adequacy of the Questionnaire of Attitudes towards "piropos" are not only promising in this study but also suggest its applicability in future studies on attitudes towards this type of SSH situation performed in Spain.

Regarding the experience of victimization, it should be noted, first of all, that nearly 8 out of every 10 participants in the sample study (79\%) had been victims of SSH on at least one occasion, with a notable difference between men (somewhat less than half, $42.6 \%$ ) and women (nearly all participants, $94.7 \%$ ). If we look not only at the total number but at the frequency, a clear pattern by gender can be observed, since SSH was a common experience for nearly one-third of the women $(29.5 \%)$ studied while affecting less than $1 \%$ of men $(0.7 \%)$. The relation between direct experience of SSH and gender detected in the sample can be extended to the general public with a probability error of less than $0.1 \%(p<0.001)$. These data not only provide an idea of the magnitude of the problem and corroborate the results obtained in previous studies carried out in Spain (i.e., [38]), they also show similar results to those previously obtained in countries such as Canada [26], the USA [9], Nicaragua [29], Chile [33], and Peru [34].

In addition, more than 8 out of every 10 participants $(84.8 \%)$ had witnessed this form of VAW on at least one occasion. This case study also identified a significant relationship with gender, given that $69.9 \%$ of males had witnessed VAW on at least one occasion as 
opposed to $89.9 \%$ of women ( $35 \%$ on a regular basis). This result not only corroborates the magnitude of the problem, it reinforces the need to further investigate new aspects, such as the behavior of those who witness this form of violence, in order to, at that develop the necessary tools to induce a proactive response to avoid and/or minimize such violence [47].

Beyond the proportion of people who had witnessed or directly experienced SSH, the ALSCAL Multidimensional Scaling used in this study provided interesting suggestions regarding the experiences of victimization endured by female participants. Specifically, the results clearly indicate that for them, theft constitutes a specific and different type of victimization, while the other types of violence under study (intimate partner violence, sexual harassment and SSH) are different, thus marking the distinctiveness of these cases as forms of VAW [1-4,6]. Additionally, being a victim of VAW by a partner or being a victim of sexual harassment is relevant to define a clear type of victimization, while in the case of SSH, the resulting group included those who had been victims or witnesses to the occurrence of SSH. It is important to remember that Multidimensional Scaling offered a very clear configuration for the subsample of women (and not for men). It stands to hypothesize that this result may be related to the characteristics of this subsample, which consisted of young women (less than 30 years of age), corresponding to the typical profile (young woman) of the primary group of victims (directly, but also as witnesses to assaults on others in their peer group) of this form of VAW [15,17,28,32,34,35]. In fact, the results obtained regarding victimization by gender and age were in accordance with this, indicating that women are witnesses to, and victims of, the different forms of VAW analyzed in this study significantly more often than men, with no difference between the age groups studied.

Regarding the effects of gender on the perception of the violence experienced, we emphasize that the results described in the literature on this topic are contradictory. While some studies have indicated the existence of a direct effect, whereby women would identify more types of behavior as forms of VAW (i.e., [53,57]), other studies indicate that gender itself does not have a direct effect, although an indirect effect, mediated by factors such as the role of gender and/or sexism, seem to exist $[18,54]$. The results found by Vallejo and Rivarola [15] provide a complementary explanation, noting a gradient in the perception, tolerance, and justification of SSH whereby, although the majority of women consider behaviors such as leering, catcalls, kissing sounds, or other comments to cause general unease, these behaviors are only identified as actual violence when they involve specific a sexual reference. However, in the specific case of individuals who had been a victim or witness to SSH, the results obtained in this study from the previously discussed Multidimensional Scaling suggest the existence of a more direct relationship between having a first-hand experience (personally or as a witness) of an incident involving SSH and the ability to identify it as such. Thus, further in-depth analysis of this matter is required in order to draw more definitive conclusions and determine possible applications to other forms of VAW. Along these lines, one relevant aspect for future investigation was noted by Delgado [12] regarding the possible effect of the presence/absence of a feminist discourse among the participants about their distinction when identifying and explaining the dynamics of assault and violence endured both in general and within an urban context.

Regarding attitudes towards "piropos", the results obtained indicate that, in general, the participants in this study demonstrated negative attitudes or rejection, which was particularly strong among women, towards these types of remarks. In fact, as expected, and as in the case of other forms of VAW [49,50,58-60], gender accounted for statistically significant differences, with women displaying much more negative attitudes towards "piropos", interpreting them as a form of VAW. A general rejection of this form of VAW was observed by age, similar to what has been described in the literature for other forms of this violence among persons of a similar age [60], but no significant differences were observed regarding attitudes towards "piropos" between the two age groups compared.

In terms of the possible role of victimization in the prediction of attitudes towards "piropos", witnessing SSH was predictive of greater rejection of "piropos" among women and younger participants and having been a victim of SSH was predictive of greater 
rejection towards "piropos" among persons between the ages of 22 and 30. This result seems to fall in line with the result sof studies carried out by Moya-Garofano et al. [37,41] in the sense that having directly received or witnessed SSH constitutes a negative life experience that an individual has endured, causing them to reject it. Further in-depth analysis of the results is required to determine the specific effects of different forms of victimization and other SSH situations.

Finally, a comparison based on other sociodemographic variables demonstrated that participants with a more left-leaning political ideology displayed a significantly greater level of rejection towards "piropos" (while those with a more right-leaning political ideology displayed the highest levels of acceptance of the subgroups analyzed). It is worth noting that previous studies highlighted effects of political affiliation on attitudes towards sexual conduct [61] and towards other forms of VAW [58], similar to the results obtained in this case and related to a more traditional understanding of the social roles of women and men and the gender mandates among individuals with more right-leaning political tendencies.

It is worth noting that this study is not without limitations. Among others is the fact that it involved a convenience sample that was primarily composed of women and young people (below the age of 30). As such, it is necessary to continue working to determine the point at which these results can be applied to other populations, especially among different age cohorts. Additionally, the use of a single questionnaire that only evaluated the attitudes towards one type of SSH situation ("piropos") is also considered a limitation of this study, although it could be compensated in the future by establishing comparisons between the results obtained with the applied questionnaire and others designed for the evaluation of perceived SSH (i.e., [39]). Likewise, further research on different aspects of SSH is required, such as, research on its components and, in particular, the possible differences in attitudes towards vulgar "piropos" (catcalls) or (supposedly) positive "piropos" [41].

Despite these limitations, the results obtained represent a notable step in achieving greater understanding of this topic that is socially relevant in our current environment. It provides a better understanding of a possible evaluation tool as well as a better understanding of the attitudes among different subsamples and their relationships with different victimization experiences.

\section{Conclusions}

This study allowed us to study "piropos", a type of stranger harassment situation, to fulfill two objectives: to determine the usefulness of a tool to evaluate social attitudes towards this form of VAW and to identify the influences of sociodemographic variables and prior victimization on attitudes towards this type of violence among the Spanish youth population.

Our results demonstrate the adequacy of the questionnaire used and its applicability for future studies on this topic. Regarding the experience of victimization, the results obtained by gender and age indicate that women are witness to, and victims of, the different forms of VAW analyzed in this study significantly more often than men, with no difference between the age groups studied. These results also suggest that there is a direct effect of gender on the perception of the violence experienced with a direct relationship between first-hand experience (personally or as a witness) of an incident involving SSH and the ability to identify it as such. In general, the participants in this study demonstrated negative attitudes or rejection towards "piropos" with no significant differences between the two age groups, but attitudes were particularly strong among women and participants with a more left-leaning political ideology.

These results have important practical and methodological implications. From a practical point of view, the results obtained represent a notable step towards achieving a greater understanding of this topic that is socially relevant in our current environment. Our results provide a better understanding of the attitudes among different subsamples and their relationships with different victimization experiences. Particularly relevant from 
the point of view of VAW prevention is the high proportion of people, especially women, who had witnessed SSH. This means, on the one hand, that it is important to train men to identify this form of violence when it occurs in public sites, and on the other hand, means that it is important to carry out programs to encourage the active intervention of witnesses to this violence to prevent it. From a methodological point of view, the results obtained provide new evidence on the use of tools to assess attitudes towards different forms of VAW.

Author Contributions: Conceptualization, V.A.F.-P. and E.B.-F.; methodology and data analysis, C.D.-A. and A.S.-P.; software, V.F.-B.; writing-original draft preparation, V.A.F.-P., E.B.-F., C.D.-A., A.S.-P. and V.F.-B.; writing-review and editing, V.A.F.-P. and A.S.-P.; supervision, V.A.F.P. All authors have read and agreed to the published version of the manuscript.

Funding: This work was financed by the Spanish State Research Agency (Agencia Estatal de Investigación), through the Research Project PID2019-104006RB-I00/AEI/10.13039/501100011033.

Institutional Review Board Statement: The study was conducted according to the guidelines of the Declaration of Helsinki and approved by the Institutional Ethics Committee of University of Balearic Islands (UIB 123CER19, 19-11-2020).

Informed Consent Statement: Informed consent was obtained from all subjects involved in the study.

Data Availability Statement: The raw data supporting the conclusions of this manuscript will be made available by the authors on request.

Acknowledgments: We would like to thank the University of Balearic Islands and the Pontifical University of Salamanca for their support in conducting the Project. We would also like to thank Miriam Miranda, Miriam Martínez, Laura Pomar and Lara Romero, collaborate students at the University of Balearic Islands, for their help in data collection.

Conflicts of Interest: The authors declare no conflict of interest.

\section{References}

1. UN (United Nations). In-Depth Study on All Forms of Violence against Women. In Report of the Secretary-General (AG 61/122/Add.1); United Nations: New York, NY, USA, 2006. Available online: https:/ / documents-dds-ny.un.org/doc/UNDOC/GEN/N06/419/ 74/PDF/N0641974.pdf?OpenElement (accessed on 10 September 2021).

2. López, M.C. Estado del arte sobre el acoso sexual callejero: Un estudio sobre aproximaciones teóricas y formas de resistencia frente a un tipo de violencia basada en género en América Latina desde el 2002 hasta el 2020. Cienc. Política 2020, 15, 195-227. [CrossRef]

3. Arancibia, J.; Billi, M.; Guerrero, M.J. ¡Tu 'piropo' me violenta! Hacia una definición de acoso sexual callejero como forma de violencia de género. Rev. Punto Género 2017, 7, 112-137. [CrossRef]

4. Rodríguez, Y.; Carrera, M.V.; Lameiras, M. Una radiografía del acoso sexual en España. In Informe España 2019; Blanco, A., Chueca, A., López-Ruiz, J.A., Mora, S., Eds.; Universidad Pontificia Comillas, Cátedra, J.M. Martín Patino: Madrid, Spain, 2019; pp. 4-58. Available online: https://blogs.comillas.edu/informeespana/wp-content/uploads/sites/93/2019/10/IE2019Parte2\%C2\%AA.pdf (accessed on 10 September 2021).

5. Rodríguez, Y.; Martínez, R.; Alonso, P. Análisis de las experiencias de mi primer acoso sexual callejero. In (Re)construíndo o coñecemento; López, A.J., Aguayo, E., Gómez, A., Eds.; Universidade da Coruña: A Coruña, Spain, 2019; pp. 421-429. Available online: https://ruc.udc.es/dspace/bitstream/handle/2183/24498/Reconstruindo_o_co\%EF\%BF\%BDecemento_20 19.pdf? sequence $=5$ (accessed on 10 September 2021).

6. UN-Women. Safe Cities Global Initiative. In Brief. 2014. Available online: http://www.unwomen.org/en/what-we-do/endingviolence-against-women (accessed on 10 September 2021).

7. Farmer, O.; Smock, S. Experiences of women coping with catcalling experiences in New York City: A pilot study. J. Fem. Fam. Ther. 2017, 29, 205-225. [CrossRef]

8. Bowman, C.G. Street harassment and the informal ghettoization of women. Harv. Law Rev. 1993, 106, 517-580. [CrossRef]

9. Kearl, H. The Facts behind the \#Metoo Movement: A National Study on Sexual Harassment and Assault; Stop Street Harassment: Reston, VA, USA, 2018. Available online: http:/ /www.stopstreetharassment.org/wp-content/uploads/2018/01/Full-Report-20 18-National-Study-on-Sexual-Harassment-and-Assault.pdf (accessed on 10 September 2021).

10. Logan, L.S. Street harassment: Current and promising avenues for researchers and activists. Sociol. Compass 2015, 9, $196-211$. [CrossRef]

11. Onetto, F.M.C. Hacia una reconceptualización del acoso callejero. Rev. Estud. Fem. 2019, 27, e57206. [CrossRef] 
12. Delgado, L.S. La utilidad del feminismo. Empoderamiento y visibilización de la violencia urbana en las mujeres jóvenes. Hábitat Soc. 2018, 11, 131-148. [CrossRef]

13. Delgado, L.S.; Aguerri, J.C. Más allá del miedo urbano de la mujer joven. Prácticas de resignificación espacial y supervivencia a la violencia en la ciudad de Zaragoza. Encrucijadas. Rev. Crítica Cienc. Soc. 2018, 15, a1502.

14. Escalona, M. Sororidad y resistencia digital ante el acoso sexual callejero. Hachetetepé. Rev. Científica Educ. Comun. 2019, 18, 124-129. [CrossRef]

15. Vallejo, E.; Rivarola, M.P. La violencia invisible: Acoso sexual callejero en Lima Metropolitana y Callao. In Cuadernos de Investigación, 4; Instituto de Opinión Pública de la Pontificia Universidad Católica de Perú: Lima, Perú, 2013. Available online: https:/ / repositorio.pucp.edu.pe/index/handle/123456789/34946 (accessed on 10 September 2021).

16. Vera-Gray, F. Men's stranger intrusions: Rethinking street harassment. Women's Stud. Int. Forum. Pergamon 2016, 58, 9-17. [CrossRef]

17. Plan Internacional. Inseguras En Las Calles. Acoso En Grupo; Plan Internacional: Madrid, Spain, 2018. Available online: http: //bbpp.observatorioviolencia.org/wp-content/uploads/2019/04/nuevo_inseguras_v05_2.pdf (accessed on 10 September 2021)

18. Angelucci, L.; Romero, A.; Marcano, T.; Aquino, S.; Carrera, A.; De Jesús, R.; Tapia, V. Influencia del sexismo, el rol sexual y el sexo sobre percepción del acoso callejero. Rev. Investigium IRE Cienc. Soc. Y Hum. 2020, 11, 28-45. [CrossRef]

19. Arancibia, J.; Billi, M.; Bustamante, C.; Guerrero, M.J.; Meniconi, L.; Molina, M.; Saavedra, P. Acoso Sexual Callejero: Contextos Y Dimensiones; OCAC (Observatorio Contra el Acaso Sexual Callejero): Santiago de Chile, Chile, 2015. Available online: https://www.ocac.cl/wp-content/uploads / 2016/09/Acoso-Sexual-Callejero-Contexto-y-dimensiones-2015.pdf (accessed on 10 September 2021).

20. Gaytan, P. El acoso sexual en lugares públicos: Un estudio desde la Grounded Theory. Cotidiano 2007, 22, 5-17. Available online: https:/ / www.redalyc.org/pdf/325/32514302.pdf (accessed on 10 September 2021).

21. McCarty, M.K.; Iannone, N.E.; Kelly, J.R. Stranger danger: The role of perpetrator and context in moderating reactions to sexual harassment. Sex. Cult. 2014, 18, 739-758. [CrossRef]

22. Brox, A. Acoso sexista callejero: ¿Qué respuesta puede ofrecer el Derecho penal? Oñati Socio-Leg. Ser. 2019, 9, 983-1000. [CrossRef]

23. Rodemann, H.R. Derechos en conflicto: Una ley anti-piropo en España. Cuest. Género Igual. Difer. 2015, 10, 51-160.

24. McNeil, P. Men Harassing Men on the Street. Guest Blog post On Feministe, 10-15-12. Available online: https:// stopstreetharassment.org/2012/10/maleharassment/ (accessed on 10 September 2021).

25. Meyer, D. An Intersectional Analysis of Lesbian, Gay, Bisexual, and Transgender (LGBT) People's Evaluations of Anti-Queer Violence. Gend. Soc. 2012, 26, 849-873. [CrossRef]

26. Macmillan, R.; Nierobisz, A.; Welsh, S. Experiencing the streets: Harassment and perceptions of safety among women. J. Res. Crime Delinq. 2000, 37, 306-322. [CrossRef]

27. Kearl, H. Unsafe and Harassed in Public Spaces: A National Street Harassment Report; Stop Street Harassment: Reston, VA, USA, 2014. Available online: https://www.stopstreetharassment.org/wp-content/uploads/2012/08/2014-National-SSH-StreetHarassment-Report.pdf (accessed on 10 September 2021).

28. Clavaud, A.; Finchelstein, G.; Kraus, F. Les femmes face aux violences sexuelles et le harcèlement dans la rue. Enquête En Eur. Et Aux Etats-Unis. 2018. Available online: https://www.jean-jaures.org/wp-content/uploads/drupal_fij/redac/commun/ productions /2018/enquete_harcelement_0.pdf (accessed on 10 September 2021).

29. Gutiérrez, N.; Lovo, E. Acoso Callejero en la Ciudad: Aproximación Descriptiva Sobre el Acoso Callejero en el Area Urbana de Managua; Observatorio Contra el Acoso Callejero Nicaragua: Managua, Nicaragua, 2015. Available online: https://www. stopstreetharassment.org/wp-content/uploads/2015/06/Informe-Acoso-Callejero-en-la-ciudad_OCAC-Nicaragua.pdf (accessed on 10 September 2021).

30. Campos, P.A.; Falb, K.L.; Hernández, S.; Díaz-Olavarrieta, C.; Gupta, J. Acoso en la calle y su asociación con percepciones de cohesión social entre mujeres en la Ciudad de México. Salud Pública México 2017, 59, 102-105. [CrossRef]

31. Meza, M.E.; García, S. Adolescent street harassment in Querétaro, Mexico. J. Women Soc. Work 2015, 30, 158-169. [CrossRef]

32. UN-Women. Safe Cities and Safe Public Spaces for Women and Girls Global Flagship Initiative: International Compendium of Practices; UN-Women: New York, NY, USA, 2019. Available online: https://www.unwomen.org/-/media/headquarters/attachments/ sections / library / publications / 2019/ safe-cities-and-safe-public-spaces-compendium-of-practices-en.pdf?la=en\&vs=2609 (accessed on 10 September 2021).

33. OCAC (Observatorio Contra el Acoso Callejero). Primera Encuesta De Acoso Callejero En Chile. Informe De Resultados; OCAC: Santiago de Chile, Chile, 2014. Available online: https:/ / www.ocac.cl/wp-content/uploads/2014/05/Informe-Encuesta-deAcoso-Callejero-2014-OCAC-Chile.pdf (accessed on 10 September 2021).

34. Llerena, R. Percepción y actitudes frente al acoso sexual callejero en estudiantes mujeres de una universidad privada de medicina. Horiz. Med. 2016, 16, 62-68. [CrossRef]

35. UN-Women. Safe Cities Global Initiative. 2015. Available online: https://www.unwomen.org/en/what-we-do/ending-violenceagainst-women/ \{\}/media/44F28561B84548FE82E24E38E825ABEA.ashx (accessed on 10 September 2021).

36. Rodríguez, Y.; Martínez, R.; Alonso, P.; Carrera, M.V. Análisis de la campaña \#PrimAcoso: Un continuo de violencias sexuales. Convergencia 2021, 28, e14300. [CrossRef]

37. Moya-Garofano, A.; Rodríguez-Bailón, R.; Moya, M.; López-Megías, J. Stranger harassment ("piropo") and women's selfobjectification: The role of anger, happiness, and empowerment. J. Interpers. Violence 2021, 36, 2306-2326. [CrossRef] 
38. Varela, S.; Caja, N.; Rueda, P. Percepción femenina del acoso callejero. Int. e-J. Crim. Sci. 2019, 14, 1-19.

39. González, H.; Cavazzoni, A.Z.; Gómez, L. Construcción y validación de un cuestionario que mide el acoso sexual callejero percibido por mujeres. Sci. Rev. Multidiscip. 2019, 6, 1-7.

40. Moya-Garofano, A. Cosificación De Las Mujeres: Análisis De Las Consecuencias Psicosociales De Los Piropos. Ph.D. Thesis, University of Granada, Granada, Spain, 2016. Available online: https://digibug.ugr.es/handle/10481/43577 (accessed on 10 September 2021).

41. Moya-Garofano, A.; Moya, M.; López-Megías, J.; Rodríguez-Bailón, R. Social perception of women according to their reactions to a stranger harassment situation (piropo). Sex Roles 2020, 83, 163-178. [CrossRef]

42. Ledezma, A.M. "Mijita Rica": The female body as a subject in the public space. Generos. Multidiscip. J. Gend. Stud. 2017, 6, 1290-1310. [CrossRef]

43. Toro, J.; Ochoa, M. Violencia de género y ciudad: Cartografías feministas del temor y el miedo. Soc. Econ. 2017, $32,65-84$.

44. Alcalde, M.C. Gender, autonomy, and return migration: Negotiating street harassment in Lima, Peru. Glob. Netw. 2018, 20, 1-17. [CrossRef]

45. Carretta, R.F.; Szymanski, D.M. Stranger harassment and PTSD symptoms: Roles of self-blame, shame, fear, feminine norms, and feminism. Sex Roles 2020, 82, 525-540. [CrossRef]

46. DelGreco, M.; Christensen, J. Effects of street harassment on anxiety, depression, and sleep quality of college women. Sex Roles 2020, 82, 473-481. [CrossRef]

47. Fileborn, B. Bystander intervention from the victims' perspective: Experiences, impacts and justice needs of street harassment victims. J. Gend.-Based Violence 2017, 1, 187-204. [CrossRef]

48. Brownmiller, S. Against Our Will: Men, Women, and Rape; Simon \& Schuster: New York, NY, USA, 1975.

49. Flood, M.; Pease, B. Factors influencing attitudes to violence against women. Trauma Violence Abus. 2009, 10, 125-142. [CrossRef] [PubMed]

50. Wang, L. Factors influencing attitude toward intimate partner violence. Aggress. Violent Behav. 2016, 29, 72-78. [CrossRef]

51. Fairchild, K.; Nguyen, H. Perceptions of victims of street harassment: Effects of nationality and hair color in Vietnam. Sex. Cult. 2020, 24, 1957-1970. [CrossRef]

52. Riquelme, A.; Herrera, M.C. Efectos del contexto y la ideología en la percepción del acoso. In Psicología Jurídica. Conocimiento Y Práctica; Bringas, C., Novo, M., Eds.; Sociedad Española de Psicología Jurídica y Forense: Santiago de Compostela, Spain, 2017; pp. 177-192.

53. Escartín, J.; Salin, D.; Rodríguez-Carballeira, A. El acoso laboral o "mobbing": Similitudes y diferencias de género en su severidad percibida. Rev. Psicol. Soc. 2013, 28, 211-224. [CrossRef]

54. Herrera, A.; Pina, A.; Herrera, M.C.; Expósito, F. ¿Mito o realidad? Influencia de la ideología en la percepción social del acoso sexual. Anu. Psicol. Jurídica 2014, 24, 1-7. [CrossRef]

55. Olivares, S.A.; González, J.A. La generación Z y los retos del docente. In Los retos de la Docencia ante las Nuevas Características de los Estudiantes Universitarios; ECORFAN Proceedings; Velasco, I., Páez, M., Eds.; Universidad Autónoma de Mayarit: Mayarit, México, 2016; pp. 116-133. Available online: https://www.ecorfan.org/proceedings/CDU_XI/PROCEEDING\%20TOMO\%2011.pdf (accessed on 10 September 2021).

56. Howe, N.; Strauss, W. Millennials Rising: The Next Great Generation; Vintage Books: New York, NY, USA, 2000.

57. Ferrer, V.A.; Bosch, E. The perception of sexual harassment at university. Rev. Psicol. Soc. 2014, 29, 462-501. [CrossRef]

58. Ferrer-Perez, V.A.; Bosch-Fiol, E.; Ferreiro-Basurto, V.; Delgado-Alvarez, C.; Sánchez-Prada, A. Comparing implicit and explicit attitudes toward intimate partner violence against women. Front. Psychol. 2020, 11, 2147. [CrossRef]

59. Gracia, E.; Lila, M. Attitudes towards Violence against Women in the EU; European Commission Directorate-General for Justice: Luxembourg, 2015. Available online: https:/ / op.europa.eu/en/publication-detail/-/publication/a8bad59d-933e-11e5-983e01aa75ed71a1/language-en (accessed on 10 September 2021).

60. Sánchez-Prada, A.; Delgado-Alvarez, C.; Bosch-Fiol, E.; Ferreiro-Basurto, V.; Ferrer-Perez, V.A. Psychosocial implications of supportive attitudes towards intimate partner violence against women throughout the lifecycle. Int. J. Environ. Res. Public Health 2020, 17, 6055. [CrossRef]

61. Saez, I.; Guijarro, C. Actitudes y experiencia sexual en mujeres jóvenes. Rev. Iberoam. Diagn. Eval.-E Avaliação Psicol. 2000, 1, 73-90. 